\title{
The geometry and stratigraphic position of the Maassluis Formation (western Netherlands and southeastern North Sea)
}

\author{
H.S.M. Jansen', J. Huizer ${ }^{2,3}$, J.W.A. Dijkmans ${ }^{3}$, C. Mesdag ${ }^{3}$ \& \\ J.E. van Hinte ${ }^{4}$ \\ ${ }^{1}$ J\&G Consultants, J.Rosenkrantzlaan 35, 2104 CC Heemstede, The Netherlands; \\ e-mail: strats@xs4all.nl \\ ${ }^{1}$ (corresponding author) \\ ${ }^{2}$ Faculty of Earth and Life Sciences, Vrije Universiteit, De Boelelaan 1085, \\ 1081 HV Amsterdam \\ ${ }^{3}$ Netherlands Institute of Applied Geoscience TNO - National Geological \\ Survey, P.O. Box 80015, NL-3508 TA Utrecht, The Netherlands; \\ e-mail: j.dijkmans@nitg.tno.nl \\ ${ }^{4}$ de Lairessestraat 78 1h, $1071 \mathrm{PH}$ Amsterdam, The Netherlands
}

Manuscript submitted: October 2002; accepted: March 2004

\begin{abstract}
The geometry and depositional history of the Maassluis Formation is described from an East-West oriented transect located in the west-central Netherlands and P- and Q-blocks in the Dutch offshore area. The Late Pliocene to Early Pleistocene Maassluis Formation was deposited under near coastal marine conditions. Two distinct facies are distinguished: (1) medium grained sands with a blocky GR/SP-log pattern that were deposited under intertidal and aeolian conditions and (2) medium to coarse grained sands deposited in a subtidal environment showing a clear coarsening upward trend. The lower part of the Maassluis Formation is laterally equivalent to the shallow marine Oosterhout Formation and gets progressively younger towards the West. The upper part is lateral equivalent to estuarine and mudflat deposits (Balk Member, c.q. Peize Formation) in the central part of The Netherlands and to river deposits (Peize Formation) further to the East.
\end{abstract}

Keywords: Maassluis Formation, marine, Late Pliocene, Early Pleistocene, depositional model

\section{Introduction}

The sandy Maassluis Formation (Doppert et al., 1975) was deposited on the southern margin of the North Sea Basin, which is bordered to the south by the London-Brabant High (Ziegler, 1990) and to the north and east by the front of the advancing Eridanos delta system sourced by the Baltic rivers (Bijlsma, 1981; Overeem et al., 2001). Fig. 1 shows the onshore correlation line, the position of the seismic line used in this study and the direction of the main sediment supply of the Maassluis Formation.

According to Doppert et al. (1975) the top of the Maassluis Formation is marked by the uppermost occurrence of marine shells, the shells being absent (or locally reworked) in overlying fluvial deposits. The sediments of the underlying Oosterhout Formation have a smaller grainsize, an increased amount of glauconite and a different mollusc assemblage.

On the basis of borehole lithological descriptions, electric log patterns and biostratigraphical data (from the digital database of TNO-NITG, DINO) an eastwest oriented correlation profile (borehole Apeldoorn (33A192) - The Hague (30D206), Fig. 1) was constructed through the Late-Pliocene and Early Pleistocene deposits of the central Netherlands, using seven boreholes (Table 1, Figs 2a and b).

The boreholes were all drilled using the airlift method (Oele et al., 1983), except for borehole De Meern (31G147), for which the suction method was used.

The onshore correlation profile was extended into the North Sea P- and Q-blocks using shallow seismic line ind95-7 (Fig. 3). The shallow seismic data al- 
Table 1 - Borehole locations used for the onshore profile. Elevations are in metres above or below Dutch Ordnance Datum (NAP)

\begin{tabular}{lllll}
\hline Location & $\begin{array}{l}\text { Code } \\
\text { (TNO- } \\
\text { NITG) }\end{array}$ & Latitude & $\begin{array}{l}\text { Longi- } \\
\text { tude }\end{array}$ & $\begin{array}{l}\text { Eleva- } \\
\text { tion }\end{array}$ \\
\hline Den Haag & $30 \mathrm{D} 0206$ & $520328.75 \mathrm{~N}$ & $41215.88 \mathrm{E}$ & 7.24 \\
Noordwijk & $30 \mathrm{~F} 0470$ & $521353.06 \mathrm{~N}$ & $42733.63 \mathrm{E}$ & 0.40 \\
Zegveld & $31 \mathrm{D} 0160$ & $520744.38 \mathrm{~N}$ & $44835.81 \mathrm{E}$ & -1.50 \\
De Meern & $31 \mathrm{G} 0147$ & $520508.66 \mathrm{~N}$ & $50120.87 \mathrm{E}$ & 1.00 \\
Baarn & $32 \mathrm{A0335}$ & $521103.75 \mathrm{~N}$ & $51313.31 \mathrm{E}$ & 5.00 \\
Ermelo & $32 \mathrm{~F} 0113$ & $521446.91 \mathrm{~N}$ & $54051.82 \mathrm{E}$ & 40.90 \\
Apeldoorn & $33 \mathrm{~A} 0192$ & $521401.55 \mathrm{~N}$ & $55235.02 \mathrm{E}$ & 87.60 \\
\hline
\end{tabular}

lowed indentification of sequence boundaries and large-scale geometries and description of stratal patterns within the deposits involved. The shallow seismic line ties in, with a slight offset, with the Noordwijk borehole (30F470, Fig. 2).

\section{Results}

\section{Onshore correlation}

Based on the log pattern, the lithology and biostratigraphy of seven boreholes, the Pliocene to Lower Pleistocene was correlated. Figs $2 \mathrm{a}$ and $2 \mathrm{~b}$ show the lithological and (partly inferred) time-stratigraphic correlation respectively. This latter correlation shows some clear trends in the sedimentary pattern, which is illustrated by the sedimentary trend seen in the FA2 foraminiferal zone (Fig. 2b, see Fig. 4 for a stratigraphic overview). This unit was deposited in a coastal environment with shell beds in the east, but grades into an open marine environment (e.g. Van Leeuwen, 1999; Munsterman, 1999) in the West (holes 30F470 and 30D206) where its log pattern shows coarsening-upward trends. The continuation to the West of this unit on the seismic profile is a clinoform extending with a gentle slope into deeper water (Fig. 3).

The same happens at the base of the FA1 zone (Fig. 2b), where the top of the unit is absent in the east, appears as a thin unit with shellbeds between 32F113 (Ermelo) and 32A335 (Baarn), and gets thicker and more clayey with coarsening-upward trends towards the West (30F470, 203 to approximately $307 \mathrm{~m}$ ).

In the Den Haag (30D206) and Noordwijk (30F470) holes the Maassluis Formation breaks up into two distinct units (Fig. 2a) with a blocky GR/SP log pattern of coastal sand at the top of the formation and a coarsening-upward log pattern interval of clayey and sandy clay units underneath. This too shows up in the offshore reflection pattern further

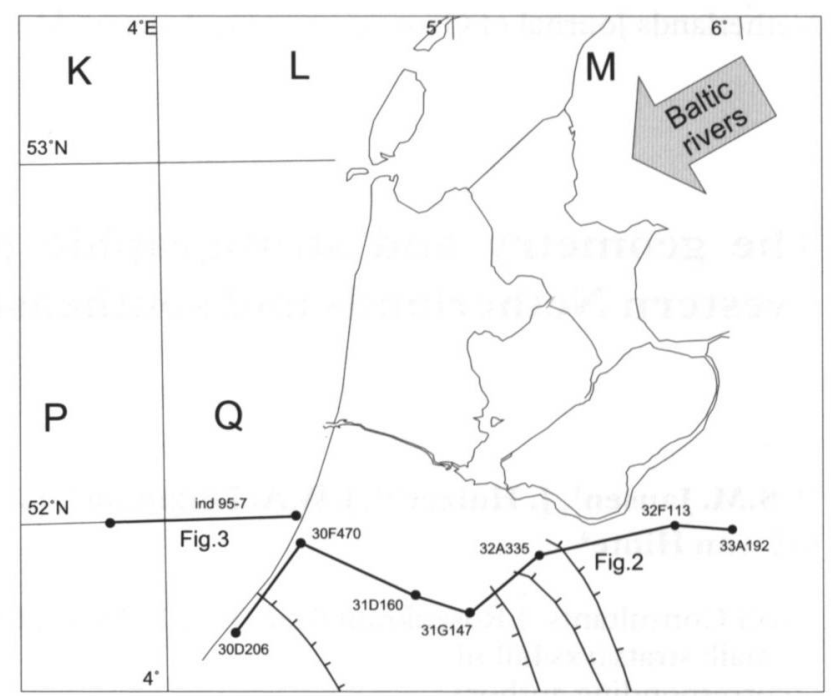

Fig. 1. Map of The Netherlands showing the location of boreholes and the East-West cross section onshore (Fig. 2), and the offshore seismic line (Fig. 3).

west, with parallel reflectors sitting on top of the clinoform units (Fig. 3).

Using the top of marine shell material of the Maassluis Formation as a marker horizon for the correlation of the borehole lithology shows that the upper unit of coastal sands in the west gives way to organic rich, estuarine or mudflat clays towards the east (Fig. 2A: Balk Member, Peize Formation). This implies that a 'Zuiderzee' precursor lined with beach barrier islands existed when the top of the Maassluis Formation was deposited. Extrapolating this trend to less marine deposits towards the East we suspect that further to the East the mudflat/estuarine deposits may grade laterally into river deposits (Peize Formation).

The marine sands of the lower unit (including those of the Oosterhout Formation) grade into coarser, coastal (Maassluis Formation) sands towards the east with hardly any intervening clay units left.

\section{Offshore correlation}

The pattern in Fig. 3 is a line drawing from the reflection pattern of seismic line ind95-7, which runs eastwest through the offshore Q- and P-blocks (Fig. 1) and can be tied to the Noordwijk (30F470) borehole with a slight offset. It shows three distinct units.

Unit 1 is made up of a set of low-angle clinoforms with near parallel seismic reflectors building out to the West. Unit 2 on top of this has steeper clinoforms and a more complex internal reflection pattern, which progrades and backsteps over the previous unit. Unit 2 is capped by Unit 3, and is characterized by parallel continuous reflectors and a channelled base. This sequence stratigraphy related terminology follows Vail et al. (1977). 

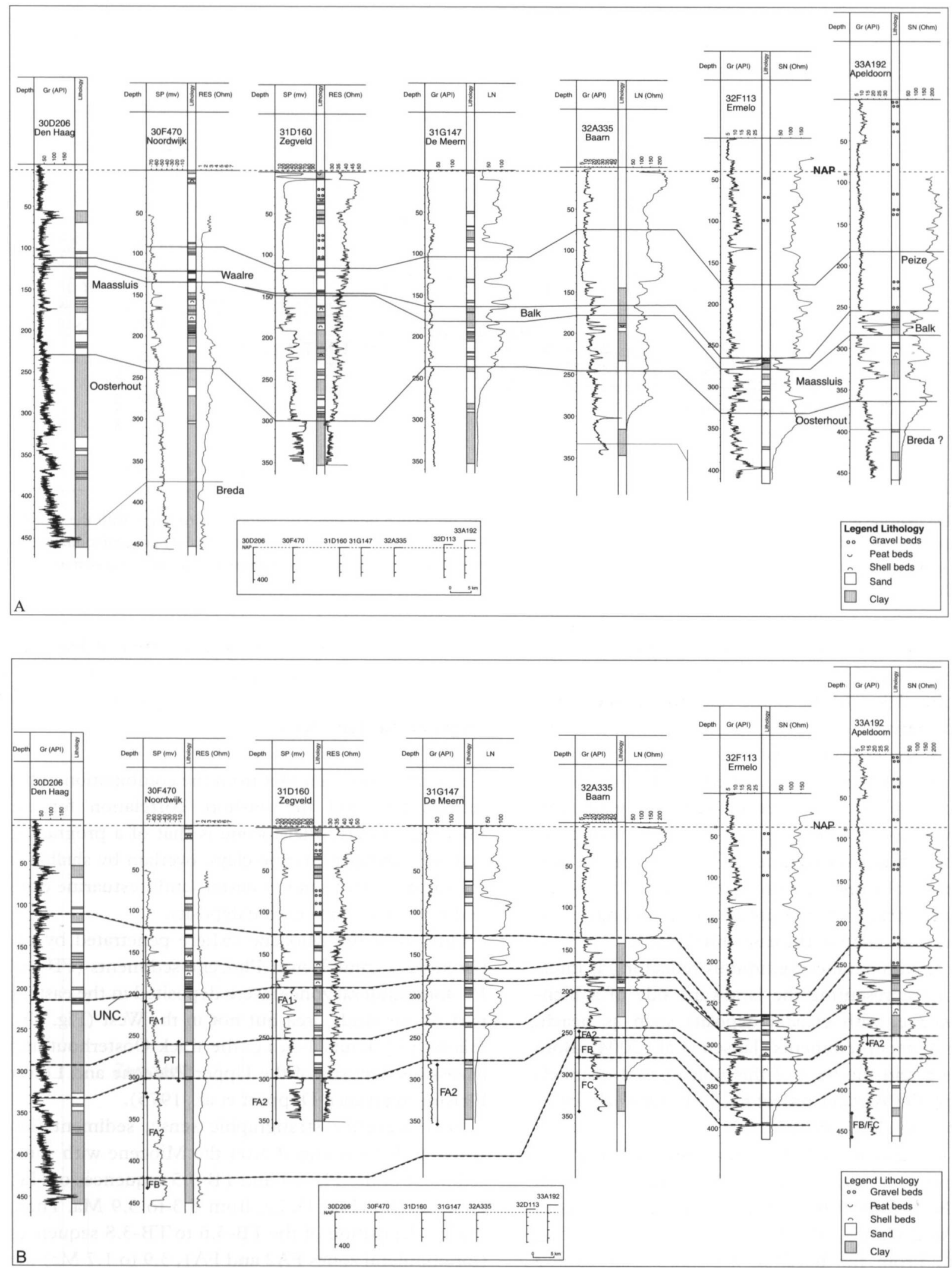

Fig 2A and 2B. Correlation of Pliocene to Pleistocene deposits in seven boreholes (see Fig. 1 for locations). Wireline logs abbreviations: GR Gamma Ray, SP - Spontaneous Potential, RES - Resistivity, LN - log normal resistivity, SN - Short normal resistivity. A: Lithostratigraphic correlation. Formations named in accordance with Weerts et al. (2000). B: Chronostratigraphic correlation. Foraminiferal zones (FA etc.) and Praetiglian pollen zone (PT) are marked. Note the facies change in the FA2 foraminiferal zone from neritic in the West to beach in the East. Note the larger amount of subsidence observed in the Ermelo borehole which is located at the southeastern rim of the Zuiderzee Basin and therefore subsiding faster than the other boreholes in the section. 


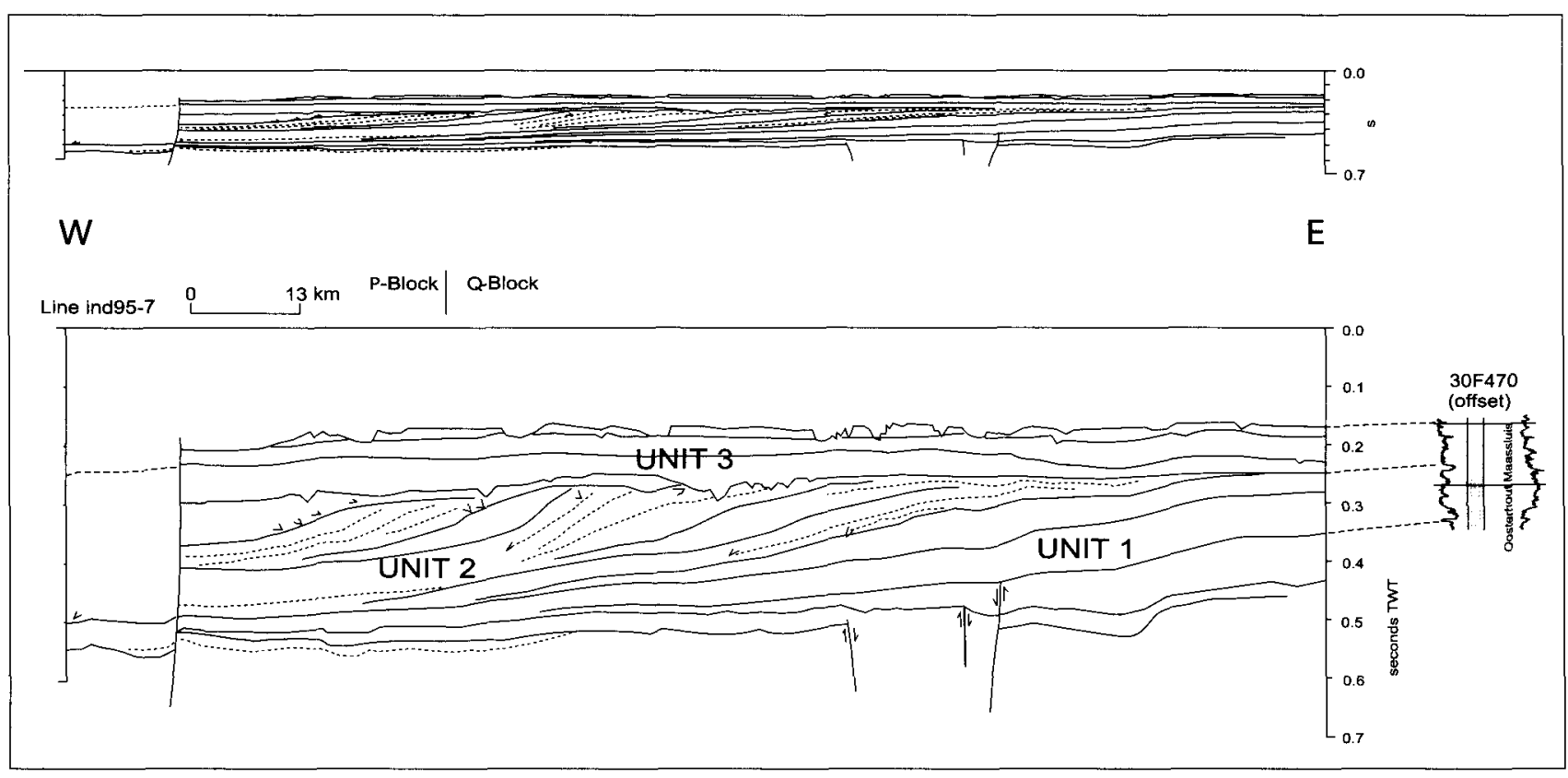

Fig. 3. Line drawing of seismic line ind95-7 through the $\mathbf{P}$ - and Q-blocks of the Dutch offshore. The tentative correlation with the onshore Noordwijk borehole is shown to the right. Note the change from low-angle aggradational clinoforms (Unit 1) to mainly progradational steeper- angle clinoforms (Unit 2). Also note the channel incisions into Unit 2 and at the top of Unit 3. Vertical scales are in two-way travel time (seconds).

Unit 1, the low-angle clinoforms, is interpreted as the distal part of a highstand wedge formed by the prograding deltas of the Baltic (and to a lesser extent the Rhine) rivers.

Unit 2, the steeper angle clinoform unit, is interpreted as a lowstand wedge, where a drop of sealevel (river base level) caused rapid outbuilding of sediment wedges and bypassing of older sediments through incised river channels. The westernmost unit of these clinoforms seems to represent the transgressive system track, with continued outbuilding to the West but also onlap to the east onto Unit 1 .

Unit 3 (with parallel continuous reflectors) is interpreted as representing the landward side of a highstand wedge, with coastal deposits such as beach, dune and marsh sediments (Jansen et al., 2004). Both at the top and the base of this unit incised channels interrupt the parallel reflectors, indicating a relative base level (sea level) drop.

The correlation of the seismic line with our onshore correlation shows that the Maassluis Formation in the Noordwijk (30F470) borehole occurs in both Unit 1 and Unit 3, with Unit 2 being absent at that location. From the borehole we know that Unit 3 consists of coastal sand with a blocky log pattern and Unit 1 has open marine sandy clay and clay with coarsening-upward log patterns at that location. The onshore correlation shows that coastal (Maassluis) sands in Unit 1 are found further to the east and are therefore older than those found in the west (in Unit
3), separated by a hiatus, which lasted at least the time it took to deposit Unit 2.

\section{Depositional model}

The picture that emerges from the combination of the seismic line and the onshore correlation for the Pliocene to Early Pleistocene is that of a prograding system with open marine clays, overlain by shallower marine clays and sands, coastal sands, estuarine clays and ultimately non-marine deposits.

On top of the Miocene (where penetrated by the boreholes), some Lower Pliocene sediments (FB and FC foraminiferal zones) were deposited in the eastern part of our study area but not in the West (Fig. 2b), followed by Units 1-3, i.e. the thick Oosterhout and Maassluis deposits of the Upper Pliocene and Lower Pleistocene (sensu Doppert et al., 1975).

In a sequence stratigraphic sense, sedimentation seems to have resumed after the Miocene with some sediment of the TB-3.4 and TB-3.5 sequences of Haq et al. (1987) (Fig. 4), i.e. from 5.3 to 3.9 Ma. Then, during deposition of the TB-3.6 to TB-3.8 sequences (foraminiferal zones FA2 and FA1, 3.9 to $1.7 \mathrm{Ma}$ ) the accumulation rate increased dramatically.

\section{Discussion}

If we use the biostratigraphic age estimates from the Noordwijk hole (Jansen et al., 2004), the base of the 


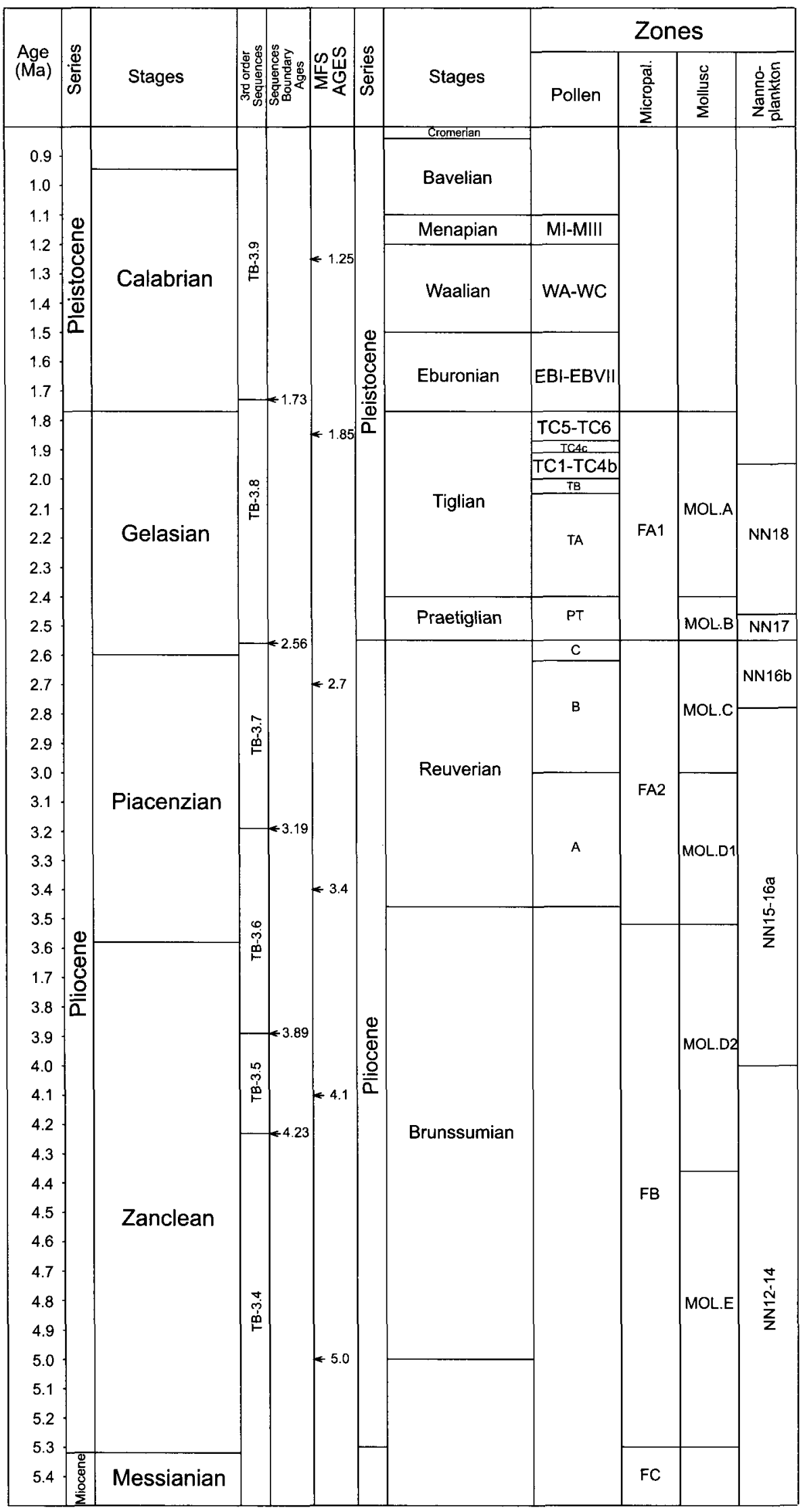

Fig. 4. Stratigraphic overview of the Pliocene and Pleistocene in The Netherlands. Numeric ages are based on Berggren et al. (1995). Benthic foraminiferal zones are after Doppert (1980), mollusc zones are after Spaink (1975) and pollen zones are after Zagwijn (1998). Sequence codes are from Haq et al. (1987) with adjusted numerical ages based on $\mathrm{De}$ Graciansky et al. (1998).
Noordwijk Maassluis Formation (upper part Unit 1, FA1 zone) falls in the Tiglian $B$ to Tiglian $C$ pollen zone range $(1.77-2.05 \mathrm{Ma}$, see Fig. 4$)$. From the seismic interpretation we infer it is not part of the TB3.8 sequence highstand (i.e. older than $1.85 \mathrm{Ma}$ ). It would therefore be a parasequence in the TB-3.8 


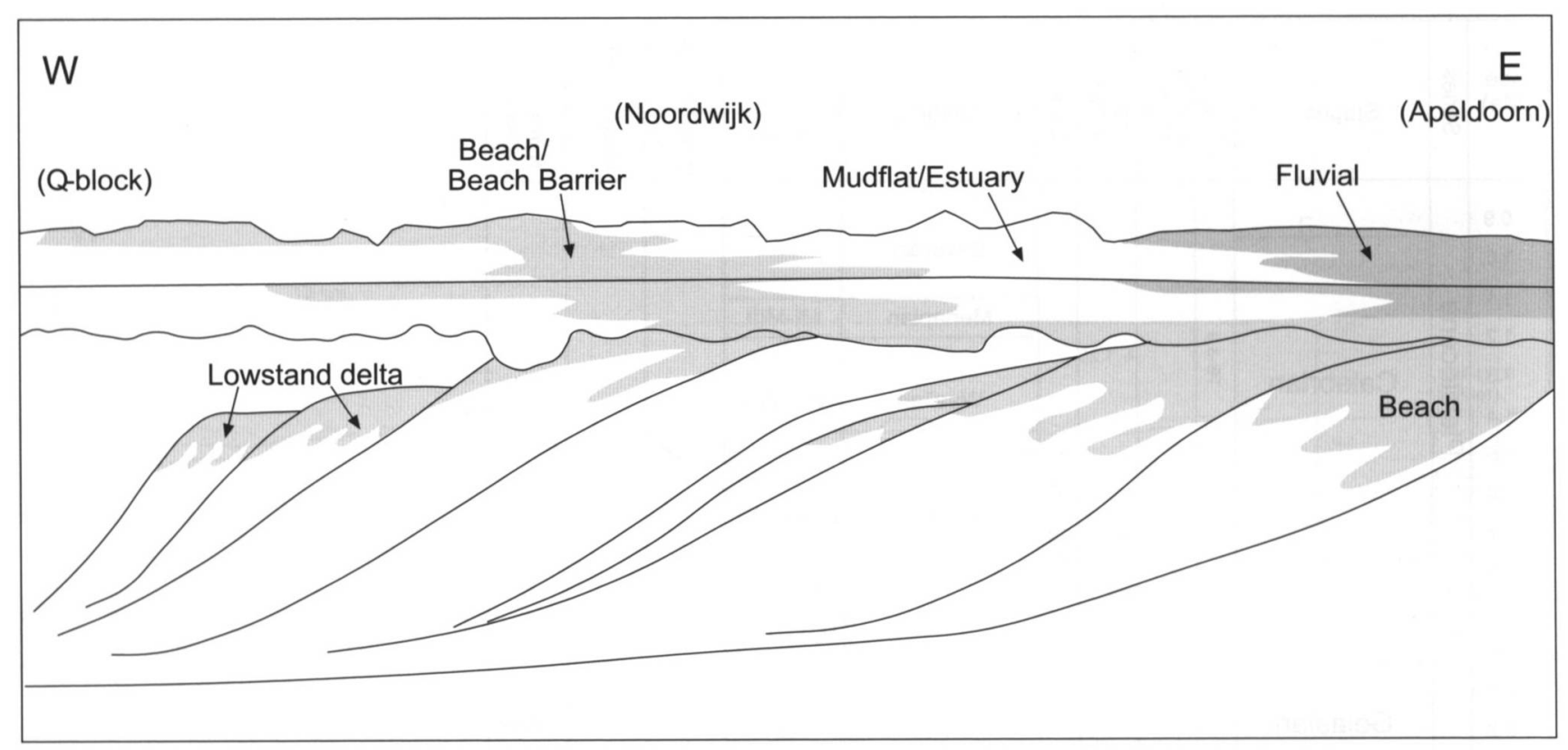

Fig. 5. Depositional model of the Maassluis Formation which combines the offshore seismics and onshore correlation. Maassluis marine deposits represent the shallow marine parts of an initially aggradational and later strongly progradational system. Strong progradation coincided with erosion of the older part of the system. Note the position of the mudflat/estuarine deposits.

transgressive systems track. The regression, which caused the deposition of Unit 2, could be due to a Tiglian C4c pollen zone cold period $(1.87-1.91$ $\mathrm{Ma}$ ). This would mean that there is a hiatus of about 0.04 (duration of Tiglian $\mathrm{C} 4 \mathrm{c}$ ) to $0.18 \mathrm{Ma}$ (to base Tiglian B) between Units 1 and 3 in the Noordwijk hole. Unit 3, the top coastal sands, would then represent the Tiglian C5 - Tiglian C6 pollen zones (the TB-3.8 highstand).

The Maassluis Formation increases in age towards the East, as shown in Fig. 2b. In the Apeldoorn (33A192) borehole area it ranges from Reuverian (FA2 foraminiferal zone, TB-3.6) to Praetiglian (as estimated from the correlation, TB-3.8) as opposed to the FA1 range in the West. In Apeldoorn it is part of Unit 1 and separated from the overlying unit by a hiatus approximately spanning top Praetiglian (2.4 Ma) to base TC5-TC6 pollen zones $(1.85 \mathrm{Ma})$, that is $0.55 \mathrm{Ma}$.

\section{Conclusions}

In consequence of its definition, i.e. a top marked by first appearance of marine shells and a base marked by first appearance of glauconite, the Maassluis Formation represents two separate facies. Facies one is made up of coastal, intertidal and aeolian dune sediments, the other by subtidal, middle to inner neritic 'toplap'-deposits.

- The Maassluis Formation is the near shore sandy equivalent of the Oosterhout Formation from at least the Reuverian through to Tiglian stages (3.4$1.77 \mathrm{Ma}$ ).

- The offshore seismic line shows that major parts of the sediment package are absent in the onshore area. These hiatuses cannot always be substantiated by biostratigraphical methods.

- In the Noordwijk area a hiatus of $0.04-0.18 \mathrm{Ma}$ between the upper and the lower part of the Maassluis Formation is inferred. In the Apeldoorn area the hiatus spans at least $0.5 \mathrm{Ma}$ between the Maassluis Formation and the Peize Formation.

\section{Acknowledgements}

This paper is a result of the project 'Process model Lower Pleistocene'. The project aims to decipher the subsurface stratal patterns of the shallow marine and deltaic Maassluis Formation to reconstruct the Late Pliocene and Early Pleistocene depositional history of The Netherlands. The project was funded by TNONITG.

\section{References}

Berggren, W.A., Kent, D.V., Aubry, M.-P. \& Hardenbol, J. (Eds), 1995. Geochronology, time scales and global stratigraphic correlation. SEPM (Tulsa): $386 \mathrm{pp}$.

Bijlsma, S., 1981. Fluvial sedimentation from the Fenno-scandian area into the north-west European basin during the late Cenozoic. Geologie en Mijnbouw 60: 337-345.

De Graciansky, P.C., Hardenbol, J., Jaquin, T. \& Vail, P.R. (Eds), 1998. Mesozoic and Cenozoic sequence stratigraphy of Euro- 
pean basins. SEPM (Tulsa): $786 \mathrm{pp}$

Doppert, J. W. Chr., Ruegg, G.H.J., Van Staalduinen, C. J., Zagwijn, W.H. \& Zandstra, J.G., 1975. Formaties van het Kwartair en Boven-Tertiair in Nederland. In: Zagwijn, W. H. \& Van Staalduinen, C. J. (Eds): Toelichting bij geologische overzichtskaarten van Nederland. Rijks Geologische Dienst (Haarlem): 114-118.

Doppert, J.W.C., 1980. Lithostratigraphy and biostratigraphy of marine neogene deposits in The Netherlands. Mededelingen Rijks Geologische Dienst 32: 255-311.

Haq, B.U., Hardenbol, J. \& Vail, P.R., 1987. Chronology of fluctuating sea levels since the Triassic. Science 235: 1156-1166.

Jansen, H.S.M., Huizer, J., Dijkmans, J.W.A. \& Van Hinte, J.E., 2004. Strontium $\left({ }^{87} \mathrm{Sr} /{ }^{86} \mathrm{Sr}\right)$ dating of marine shells from Pliocene and Pleistocene shallow marine deposits in The Netherlands. Netherlands Journal of Geosciences 83/1, 47-54.

Munsterman, D.K., 1999. De resultaten van het dinoflagellatenonderzoek aan boring 30F470 (Noordwijk), traject: 131.25 $454.10 \mathrm{~m}$. TNO rapport NITG-99-108-B: 1-8.

Oele, E., Apon, W., Fischer, M.M., Hoogendoorn, R., Mesdag, C.S., De Mulder, E.F.J., Overzee, B., Sesören, A. \& Westerhoff, W.E., 1983. Surveying the Netherlands, Sampling Techniques, Maps and their application. Geologie en Mijnbouw 62:355-372.

Overeem, I., Weltje, G.J., Bishop-Kay, C. \& Kroonenberg, S.B., 2001. The Late Cenozoic Eridanos delta system in the Southern North Sea basin: a climate signal in the sediment supply? Basin Research 13: 293-312.

Spaink, G., 1975. Zonering van het mariene Onder-Pleistoceen en Plioceen op grond van molluskenfauna's. In: Zagwijn, W. H. \& Van Staalduinen, C. J. (Eds): Toelichting bij geologische overzichtskaarten van Nederland. Rijks Geologische Dienst (Haarlem): 118-122.

Vail, P.R., Mitchum, R.M. \& Thompson, S. III, 1977. Seismic stratigraphy and global changes of sea level, part 11: Glossary of terms used in seismic stratigraphy. In: Payton, C.E. (Ed.). Seismic stratigraphy applications to hydrocarbon exploration. American Association of petroleum geologists Memoir 26: 205-212.

Van Leeuwen, R.J.W., 1999. Foraminiferenonderzoek aan de boring Noordwijk 30F470. TNO rapport NITG-99-145-B: 1-8.

Weerts, H.J.T., Cleveringa, P., Ebbink, J.H.J. \& Westerhoff, W.E., 2000. De lithostratigrafische indeling van Nederland - Formaties uit het Tertiair en Kwartair. Rapport TNO-NITG 00-95A.

Zagwijn, W.H., 1998. Borders and boundaries: a century of stratigraphical research in the Tegelen-Reuver area of Limburg (The Netherlands). Mededelingen Nederlands Instituut voor Toegepaste Geowetenschappen TNO 60: 19-34.

Ziegler, P.A., 1990. Geological Atlas of Western and Central Europe $\left(2^{\text {nd }}\right.$ edition). Shell Internationale Petroleum Maatschappij: $239 \mathrm{pp}$. 